of the Conference. Ground investigations are continuing in Cornwall and it will be some time before all data recorded from the air have been assessed.

\section{Design in Industry}

MANY interesting suggestions concerning the education and training of designers for the furniture, pottery, printing and textile industries are contained in "The Training of Designers for Industry" ( $p p$. vii +50. Federation of British Industries, 21 Tothil Street, London, S.W.1, 1957. 3s. 6d.). 'This is the report of a one-day conference between industrialists and educationists, organized under the auspices of the Federation of British Industries and held in London on September 24, 1957. The booklet includes the opening address by Sir Edward Boyle, Parliamentary Secretary to the Ministry of Education, and reports by the chairmen of the five discussion groups on important points made in the course of the conference, together with a summing-up by Sir Ernest Goodale, chairman of the Federation's Industrial Art Committee. It also includes the memoranda circulated bofore the ronference as bases for the group discussions.

\section{National Science Foundation Programme for Atmo- spheric Sciences}

AN Atmospheric Sciences Programme is being established by the U.S. National Science Foundation as a result of recommendations by the President's Committee on Weather Control and the Committee on Meteorology of the National Academy of Sciences -National Research Council. The new programme will deal with meteorology, including not only the more conventional type of meteorological research, but also energy transfer processes between earth, sea and air; turbulent flow of gaseous fluids; heat exchange processes; upper atmosphere studies (that is, above the level of conventional meteorological work); atmospheric chemistry; and general circulation problems of the atmosphere and oceans. Attention will also be given to the field of cloud physics, especially the physics of precipitation, where much basic research must be pursued before the possibilities of controlling or modifying weather can be evaluated. The programme director will be Dr. Earl G. Droessler, who has wide experience in administration and co-ordination of military scientific research and development, and in research in meteorology and glaciology.

\section{Agricultural Meteorology in India}

A sPECIAL issue of the Indian Journal of Meteorology and Geophysics was published in December 1957 in honour of the silver jubilee of the Agricultural Meteorology Division of the India Meteorology Department. The importance of the scientific study of the relations between crops and weather has long been recognized, notably early in this century in Britain by Sir Napier Shaw, and the International Meteorological Organization formed its Commission for Agricultural Meteorology in 1913. It is, however, only in relatively recent years that stations specifically equipped and staffed by meteorological physicists have been set up to make detailed micrometeorological and related observations. India, under Sir Charles Normand's tenure of the post of DirectorGeneral of Observatories, was one of the first countries to establish such a unit. The Division was formed at Poona in 1932 and placed under Dr. L. A. Ramdas, who remained in charge until 1953.
The Central Agricultural Meteorological Observ. atory is on the farm of the Agricultural College at Poona. It is equipped with instruments for observing the micro-structure of the atmosphere up to $35 \mathrm{ft}$. in the free air and within crops, and also radiation, evaporation, soil properties and plant temperatures. The Division also controls less detailed meteorological work at some forty other experimental farms in India, and maintains weekly charts of the relevant weather elements and of the progress of crops all over India. The major work now in progress is concerned with the water requirements of plants, the relation between weather and the incidence of disease and pests and the preparation of crop-weather calendars for the guidance of regional meteorological centres in the preparation of the weather forecasts for the farmers' weather bulletins. It was at this Division that the observation was first made that under clear sky at night the air just above ground is often colder at a height of $5-15 \mathrm{~cm}$. than at the ground itself. This observation, scarcely credited for a time, has been repeated at several places elsewhere with other ty pes of apparatus but is still not fully explained.

University College, London : Report for 1956-57

THE annual report of University College, London, for 1956-57 (pp. 89. London: University College, 1958) includes the report of the chairman of the College Committee and the provost, together with those of the Students' Union, the Bartlett School of Agriculture and the Slade School of Fine Art, and lists of publications of members of academic departments. Of the $\mathbf{3 , 5 7 4}$ students (including 795 part-time) 755 were postgraduate (239 part-time). Some 589 undergraduates and 318 postgraduates were in the faculty of science and 206 undergraduates and 66 postgraduates in engineering. The year was the last of the old quinquennium, which closed with a deficit of $£ 2,455$, and the report, commenting on the absence of general funds for research, records the severe disappointment with the grant from the University Grants Committee for the new quin. quennium: that of $£ 1,165,000$ for $1957-58$ will permit no academic expansion and will necessitate a substantial cut in maintenance. Capital expenditure of $£ 280,000$ was concentrated on the new Biological Sciences Block, but the planning of the first stage, to cost $£ 500,000$, of the new Engineering Building is well advanced. In the Department of Chemistry investigations of the mechanisms of reactions in solution have recently been correlated with studies of reactions in the gas phase, and some main lines of investigation have been greatly facilitated by the installation of a nuclear magnetic resonance apparatus through the generosity of the Wellcome Trust. In the Department of Physics assembly of the microtron has proceeded satisfactorily (see Nature, June 21, p. 1726), and the new high-pressure cloud chamber has been assembled and tested.

\section{Arthur D. Little Research Institute}

THE first annual report of the Arthur D. Little Research Institute (Inveresk, Midlothian), inaugurated on March 22, 1957, records that on December 31 the Institute's staff totalled twenty-two, of whom twelve were qualified scientists. The three projects under investigation at that date embraced a general study of linear polymers of spatially regular structures, including the mechanism and kinetics of formation of such polymers and their physical properties; a 